\title{
Międzynarodowe seminarium „Classification and Authority Control: Expanding Resource Discovery" (Lizbona, Portugalia, 29-30 października 2015 r.)
}

W dniach 29-30 października 2015 r. w gmachu Biblioteki Narodowej w Lizbonie odbyło się międzynarodowe seminarium zatytułowane "Classification and Authority Control: Expanding resource discovery”, zorganizowane przez Konsorcjum UKD i Bibliotekę Narodową Portugalii. W seminarium udział wzięło 95 delegatów z 26 krajów, specjalistów informacji, klasyfikacji i indeksowania, naukowców oraz studentów w zakresie organizacji informacji i wiedzy. Celem seminarium było zaprezentowanie stanu badań poświęconych tematyce klasyfikacji oraz kontroli bibliograficznej w środowisku sieciowym. Zwrócono uwagę na dwa aspekty kontroli autorytatywnej. Po pierwsze, mającej usprawniać współpracę między różnymi słownikami, tak aby uniknąć redundancji i niespójności w reprezentacji i przetwarzaniu informacji, po drugie - zapewnić interoperacyjność połączonych danych. Program seminarium składał się sześciu z 26 prezentacji i posterów.

W problematykę obrad wprowadził wykład zaproszonego gościa, prof. Michaela Bucklanda (School of Information, University of California, USA), zatytułowany Classifications, links and contexts. Zwrócił on uwagę na znaczenie relacji pomiędzy pojęciami, ich semantyczną, kulturową i kontekstową determinację. Przywołując, prezentowaną w pracach Paula Otleta modernistyczną, globalną wizję relacji zachodzących pomiędzy wyrażeniami, w tym wyrażeniami języków informacyjno-wyszukiwawczych (JIW), zestawił ją z wizją, w której widoczny jest wpływ lokalnych kontekstów kulturowych na te relacje. Cytując Ludwika Flecka, polskiego mikrobiologa, podkreślił znaczenie kontekstu kulturowego dla właściwego zrozumienia sensu wyrażenia. Skuteczne wyszukiwanie informacji jest według niego zawsze zdeterminowane lokalnymi uwarunkowaniami funkcjonowania danego języka. Poszczególne wyrażenia języka mogą być przez różnych użytkowników informacji wyszukiwane w sposób zróżnicowany, uzależniony od posiadanych kompetencji językowych czy też posiadanej wiedzy specjalistycznej bądź fachowej.

Konferencję podzielono na sześć sesji tematycznych. W sesji pierwszej pod tytułem „Past and future perspectives on subject data assets” podjęto ogólne rozważania na temat zarządzania dany$\mathrm{mi}$ w sieci. W referacie Complementarity of perspectives for resource descriptions Barbara B. Tillett (Washington, DC, USA) zwróciła uwagę na zagadnienia komplementarności opisu danych oraz publikowania danych bibliograficznych i kartotek wzorcowych zgodnie z modelem danych powiązanych. Podkreślił, że dzięki technologiom Linked Open Data (LOD) gromadzone w OPAC metadane są łatwiej dostępne zarówno dla ludzi, jak i komputerów.

W kolejnym referacie Libraries, classifications and the network: bridging past and future Maria Ines Cordeiro (National Library of Portugal) zwróciła uwagę na zbyt małe wykorzystanie klasyfikacji bibliotecznych w środowisku sieciowym. Według autorki, rozwój technologii internetowych pozwolił wprawdzie na wykorzystanie koncepcji połączeniai udostępniania danych za pomocą linked data, wciąż jednak brakuje inteligentnych sposobów, aby skutecznie łączyć i przekazywać dane w całej sieci, w synchroniczny i nieredundantny sposób.

W prezentacji Library linked data: contributions and role of linked subject data Nuno Freire (The European Library, Holandia), jak jego poprzedniczka, nawiązał do idei zbiorów połączonych. Autor omówił przypadek Biblioteki Europejskiej, umożliwiającej zintegrowane przeszukiwania zarówno katalogów bibliotecznych, jak i kolekcji zawierających zbiory w postaci cyfrowej. 
Sesja druga pt. „Data models and semantic structures” odnosiła się do wymienionych w tytule zagadnień modeli danych oraz struktur semantycznych. W referacie Application of FRBR and FRSAD to classification systems Maja Žumer (University of Ljubljana, Słowenia) oraz Marcia Lei Zeng (Kent State University, USA) postawiły pytanie, czy modele konceptualne Functional Requirements for Bibliographic Records (FRBR) oraz Functional Requirements for Subject Authority Data (FRSAD) mogą być zastosowane do modelowania systemów klasyfikacyjnych, m. in. Uniwersalnej Klasyfikacji Dziesiętnej (UKD) i Klasyfikacji Dziesiętnej Deweya (KDD)?

Wystąpienie Rebeki Green (OCLC, USA), Relational aspects of subject authority control: the contributions of classificatory structure, dotyczyło reprezentowania semantycznych związków między wyrażeniami JIW w kontekście ich stosowania w kartotekach wzorcowych.

Violeta Ilik (Northwestern University, Chicago, USA) w referacie Distributed person data: using Semantic Web compliant data in subject name headings odniosła się do kwestii wykorzystania Sieci Semantycznej do zgromadzenia jak największej liczby informacji na temat osób. Zwróciła uwagę, że informacje na temat określonej osoby znajdują się często w bazach danych rozproszonych i charakterystycznych dla danej dziedziny wiedzy, co powoduje, że dotarcie do nich wymaga tworzenia takich standardów opisywania treści w Internecie, które umożliwiają systemom komputerowym semantyczne przetwarzanie informacji na podstawie identyfikacji zawartych w nich treści.

Sesja trzecia pt. „Authority control design and classification” poświęcona została kontroli autorytatywnej. Dagobert Soergel (University of Buffalo, USA) i Denisa Popescu (World Bank Group, Washington, USA) w referacie Organization authority database design with classification principles omówili kwestie ujednoliconych zasad strukturyzowania danych organizacyjnych (nazw organizacji i ich części) z wykorzystaniem struktur hierarchicznych. W ten sposób zorganizowane ontologie nazw organizacji i ich części strukturalnych mogą poprawić sprawność wyszukiwania danych o organizacjach i powiązaniach między nimi.

Ulf Schöneberg i Wolfram Sperber (FIZ Karlsruhe, zbMATH, Niemcy) w referacie Machine-learning methods for classification and content authority control in mathematics zogniskowali uwagę na zbMATH, najbardziej kompleksowej bazie danych bibliograficznych literatury matematycznej. W ciągu ostatnich kilku lat zespół ZbMATH rozpoczął opracowywanie koncepcji i narzędzi do tworzenia słowników kontrolowanych oraz do usprawnienia i rozwoju Mathematics Subject Classification (MSC). Przyjęte koncepcje przetwarzania języka naturalnego i inne metody uczenia maszynowego zostały dostosowane do specyficznych wymagań informacji matematycznej. Zastosowane narzędzia służą do poprawienia użyteczności i możliwości wyszukiwania informacji w bazie danych zbMATH.

Drugiego dnia konferencji odbyły się trzy sesje. Pierwszą z nich zatytułowaną „Classifications in subject access authority control” poświęcono kontroli autorytatywnej za pomocą kartotek wzorcowych w Czechach, w Szwajcarii i w Chorwacji. Maria Balíková (Czech National Library, Czechy) w referacie Subject authority control supported by classification:the case of National Library of the Czech Republic omówiła prace związane z utrzymaniem i rozwojem czeskiej kartoteki wzorcowej CZENAS.

Jiri Pika (UDC Editorial Team, UDC Consortium, Szwajcaria) oraz Milena Pika-Biolzi (ETH-Bibliothek, Szwajcaria) w referacie Multilingual subject access and classification-based browsing through authority control: the experience of ETH-Bibliothek, Zürich opisali sposoby sprawowania kontroli autorytatywnej w kartotece wzorcowej Netzwerk von Bibliotheken und Informationsstellen in der Schweiz (NEBIS).

Ana Vukadin (National and University Library in Zagreb, Chorwacja) w referacie The development of a classification oriented authority control: the experience of National and University Library in Zagreb przedstawiła doświadczenia z tworzenia kartoteki wzorcowej UKD w Bibliotece Narodowej i Uniwersyteckiej w Zagrzebiu. Projekt, którego realizację rozpoczęto w 2014 r. ma na celu ułatwienie zarządzania danymi, poprawę spójności indeksowania i czytelności danych dla wymiany i ponownego użycia w środowisku internetowym. 
W sesji piątej zatytułowanej "Strategies and innovation with classification in libraries" i szóstej pt. "Issues and opportunities for classification data", uwagę zogniskowano na innowacjach mających na celu poprawę funkcjonowania klasyfikacji w środowisku sieciowym, sposobach analizy i interpretacji symboli klasyfikacyjnych. W prezentacji TinREAD - an integrative solution for subject authority control Victoria Frâncu (Carol I Central University Library Bucharest, Rumunia) oraz Liviu-Iulian Dediu (IME Romania Ltd., Rumunia) omówili kwestie związane z funkcjonowaniem produkowanego przez Information Management Engineering zintegrowanego systemu bibliotecznego pod nazwą "The Information Navigator for Readers” (TinREAD). Jest to narzędzie, które obsługuje tezaurus klasyfikacji, w ramach którego wielojęzyczne słowne terminy indeksowe są przypisane do symboli klasyfikacyjnych.

W kolejnym referacie zatytułowanym Alignment in medical sciences: towards improvement of UDC Olívia Pestana (University of Porto, Portugalia) porównała zakres i zasięg słownictwa klasyfikacji medycznej National Library of Medicine oraz słownictwo działu 61 - Medycyna w UKD. Autorka zwróciła uwagę na opóźnienia w rewizji symboli UKD w zakresie nauk medycznych, co stanowi przeszkodę dla lepszego wykorzystania tej klasyfikacji.

W referacie Commerce, see also Rhetoric: cross-discipline relationships as authority data for enhanced retrieval Claudio Gnoli (University of Pavia, Włochy), Rodrigo De Santis (Paraná Federal Institute of Education Science \& Technol., Irati, Brazylia), Laura Pusterla (University of Pavia, Włochy) zaprezentowali SciGator, interfejs umożliwiający wyszukiwanie w zbiorach wszystkich bibliotek naukowych na Uniwersytecie w Pawii. Interfejs ten pokazuje użytkownikom klasy powiązane, pozostające $w$ relacjach semantycznych i pozwala na zadawanie rozbudowanych zapytań. W budowaniu interfejsu SciGator użyto Web Ontology Language (OWL), który pozwala na tworzenie czytelnych dla komputerów opisów semantycznej zawartości zasobów informacyjnych.

W referacie Managing classification in libraries - a methodological outline for evaluating automatic subject indexing and classification in Swedish library catalogues Koraljka Golub, Joacim Hansson (Linnaeus University, Szwecja), Dagobert Soergel (University of Buffalo, USA) i Douglas Tudhope (University of South Wales, Wielka Brytania) opisali metodologię oceny narzędzi, użytych w klasyfikowaniu zgodnym z KDD i indeksowaniem zgodnym ze Swedish Subject Headings w bibliotekach szwedzkich.

W kolejnej prezentacji, zatytułowanej Automatic interpretation of complex UDC numbers: towards support for library systems Attila Piros (University of Debrecen, Węgry) przedstawiła narzędzie do automatycznej analizy symboli UKD, w tym symboli złożonych. Autorzy tego narzędzia podjęli się zadania opracowania oprogramowania do analizy symboli UKD, który jest w stanie rozpoznać i opisać części symboli wraz z relacjami zachodzącymi między nimi, w różnych formatach wymiany danych.

Andrea Scharnhorst, Christophe Guéret, Alkim Almila Akdag Salah (eHumanities DANS/KNAW, Holandia) oraz Richard P. Smiraglia (University of Wisconsin, Milwaukee, USA) w referacie Knowledge maps for libraries and archives - uses and use cases przedstawili możliwości wykorzystania map wiedzy i wizualizacji do prezentacji struktury zbiorów sklasyfikowanych za pomocą UKD oraz nawigacji po tej strukturze. Analizie poddano symbole UKD użyte do sklasyfikowania zbiorów bibliograficznych Biblioteki Narodowej Portugalii.

W ostatnim referacie wygłoszonym na konferencji, zatytułowanym $A$ second life for authority records Shenghui Wang i Rob Koopman (OCLC, Holandia) zwrócili uwagę na niepełne i niewłaściwe wykorzystanie w praktyce symboli klasyfikacji. W ich ocenie może to być spowodowane błędami w rekordach wzorcowych bądź niewłaściwym, niezgodnym z intencją stosowaniem symboli, jak również wybiórczym stosowaniem symboli, które wykorzystywane są $\mathrm{w}$ wybranych instytucjach, bądź w ramach danej instytucji tylko w wybranych komórkach organizacyjnych. Z analizy wynika, że gdy zapytanie użytkownika oparte jest na symbolach klasyfikacyjnych, wyniki mają zwykle dużą precyzję, lecz ich wykorzystanie jest zwykle rzadkie.

W sesji posterowej przedstawionych zostało sześć prezentacji. W czterech z nich podjęto problematykę kontroli autorytatywnej w zakresie UKD. Autorami posteru Subject information and 
multilingualism in European bibliographic datasets: experiences with Universal Decimal Classification byli Nuno Freire, Valentine Charles, Antoine Isaac (The European Library, Holandia). Poster Enhancing subject authority control at the UK Data Archive: a pilot study using UDC przygotowała Suzanne Barbalet (UK Data Archive, University of Essex, Wielka Brytania). Darija Rozman (The National and University Library, Ljubljana, Słowenia) przedstawiła poster Experience with UDC updates: the Slovenian perspective, a Elena Cardillo, Iryna Solodovnik, Maria Taverniti (Institute of Informatics and Telematics, National Research Council, Rende, Włochy) przedstawili poster Towards the creation of integrated authority files in the domain of science and technology: an Italian use case.

Poster The Basel Register of Thesauri, Ontologies \& Classifications (BARTOC) przygotował Andreas Ledl (University Library of Basel, Szwajcaria). Wymieniony w tytule referatu Basel Register of Thesauri, Ontologies E Classifications (BARTOC) to wielojęzyczna, interdyscyplinarna baza danych dla systemów organizacji wiedzy, opracowana przez Bibliotekę Uniwersytecką w Bazylei, zawierająca 1500 słowników w 85 językach z różnych dziedzin wiedzy.

W posterze Visualisation of Warsaw University of Technology Main Library resources based on UDC autorzy Agnieszka Maria Kowalczuk, Łukasz Skonieczny i Małgorzata Wornbard (Politechnika Warszawska, Polska) zaprezentowali projekt wizualizacji zbiorów Biblioteki Głównej Politechniki Warszawskiej, opisanych za pomocą symboli UKD.

Konferencję zakończyła dyskusja, której przedmiotem były kluczowe dla spotkania problemy: klasyfikacje w środowisku sieciowym, kontrola autorytatywna, wymiana danych o określonej strukturze i wzajemne wykorzystywanie tych danych w celu utworzenia z nich informacji, a także zachodzące w językach informacyjnych relacje paradygmatyczne i syntagmatyczne. Materiały z konferencji udostępniono na stronie UDC Consortium: http://seminar.udcc.org/2015/programme.php.

Jolanta Hys

Biblioteka Narodowa

Nadestano: 13 listopada 2015. 